\title{
HUBUNGAN ANTARA ADVERSITY QUOTIENT (AQ) DENGAN HASIL BELAJAR MATEMATIKA
}

\author{
Ni Luh Citra Pertiwi \\ Program Studi Teknologi Pendidikan, Universitas Pendidikan \\ Ganesha citrapertiwi408@gmail.com \\ I Wayan Wiarta \\ Program Studii Teknologi Pendidikan, Universitas Pendidikan \\ Ganeshaiwayan.wiarta@undiksha.ac.id \\ I Ketut Ardana \\ Program Studii Teknologi Pendidikan, Universitas Pendidikan \\ Ganesha iketut_ardana55@yahoo.com
}

\begin{abstract}
Abstak
Penelitian ini bertujuan untuk mengetahui hubungan antara adversity quotient (AQ) dengan hasil belajar matematika siswa kelas V SD Gugus VI Abiansemal Tahun Ajaran 2017/2018. Jenis penelitian ini adalah penelitian ex post facto, korelasional. Populasi dari penelitian ini adalah seluruh siswa kelas V SD Gugus VI Abiansemal Tahun Ajaran 2017/2018 yang banyaknya 165 orang. Sampel diambil dari populasi dengan menggunakan teknik sampling proporsional dan random sampling dan banyak sampel dari populasi ini adalah 114 orang. Data yang dikumpulkan adalah hasil dari pengisian angket tentang adversity quotient (AQ), sedangkan data tentang hasil belajar matematika didapat melalui pencatatan dokumen. Data dianalisis dengan menggunakan teknik analaisis korelasi product moment. Hasil analisis data menunjukkan koefisien korelasi antara adversity quotient (AQ) dengan hasil belajar matematika sebesar rxy $=0,537$ dan rtabel $=0,184(0,537>$ $0,184)$ dan koefisien determinasi sebesar $28,84 \%$, serta thitung $=6,738$ dan ttabel $=1,981(6,738>1,981)$ dengan $\mathrm{df}=$ 112, uji dua pihak pada taraf signifikansi 5\%. Maka dapat disimpulkan bahwa hipotesis nol (H0) ditolak dan hipotesis alternatif (Ha) diterima. Jadi dapat disimpulkan bahwa terdapat hubungan yang signifikan antara adversity quotient (AQ) dengan hasil belajar matematika siswa kelas V SD Gugus VI Abiansemal Tahun Ajaran 2017/2018. Penelitian ini diharapkan dapat memperkaya teori dan sumber untuk penelitian yang sejenis.
\end{abstract}

Kata Kunci: Adversity Quotient (AQ), hasil belajar matematika

\begin{abstract}
This research was aimed at determining the correlation between the adversity quotient (AQ) with the Mathematics learming result of the fifth-grade students of Elementary School Gugus VI Abiansemal in the academic year 2017/2018. The research used correlational ex-post facto design. The population of this research was all of the fifth-grade students of Elementary School Gugus VI Abiansemal in the academic year 2017/2018 which consisted of 165 students. The sample was obtained using proportional sampling and random sampling consisting of 114 students. The obtained data were the result of questionnaire of Adversity Quotient (AQ), while the data of Mathematics learning result were obtained using documentation. The data were analyzed using correlation technique of Product Moment. The result of data analysis showed the correlation between adversity quotient (AQ) and the Mathematics learning result with $\mathrm{rxy}=0,537$ and rtab $=0,184$ $(0,537>0,184)$. The determination coefficient was $28,84 \%$, tcal $=6,738$, ttab $=1,981(6,738>1,981)$ with $\mathrm{df}=112$, and the two-sided test on the significance level was $5 \%$. It can be concluded that null hypothesis (H0) was rejected and alternative hypothesis (Ha) was accepted. So it can be concluded that there is a significant correlation between adversity quotient (AQ) and the Mathematics learning result of the fifth-grade students of Elementary School Gugus VI Abiansemal in the academic year 2017/2018. This study is expected to enrich theories and sources for similar research.
\end{abstract}

Keywords: Adversity Quotient (AQ), Mathematicslearning result

\section{Pendahulan}

Dalam proses pembelajaran di sekolah, setiap siswa diharapkan dapat memperoleh hasil belajar yang baik dan optimal karena sebuah parameter keberhasilan yang digunakan untuk mengukur tingkat keberhasilan pendidikan dan pembelajaran yang ditempuh oleh siswa adalah hasil belajar. Dalam pendidikan formal, hasil belajar yang dicapai oleh siswa dalam usaha belajarnya biasanya terlihat dalam bukti fisik berupa rapor. Semakin baik hasil rapor menandakan bahwa siswa tersebut mendapatkan hasil belajar yang baik. Tetapi, dalam meraih suatu hasil belajar ada yang lebih penting dari sekedar hasil belajar yang baik yaitu proses belajar.

Proses belajar merupakan hal penting karena belajar merupakan salah satu faktor yang sangat berperan dalam pembentukan pribadi dan perilaku individu sebagai hasil dari pengalaman individu itu dalam berinteraksi dengan lingkungannya. Belajar ialah suatu proses usaha yang dilakukan seseorang untuk memperoleh suatu perubahan tingkah laku yang baru secara keseluruhan, sebagai hasil pengalamannya sendiri 
dalam interaksi dengan lingkungannya (Slameto, 2010: 2). Jadi, belajar merupakan suatu proses untuk membuat suatu perubahan perilaku dalam diri seseorang dengan cara berinteraksi dengan lingkungan.

Istilah mengajar dan belajar adalah dua peristiwa yang berbeda, tetapi terdapat hubungan yang erat, bahkan terjadi kaitan dan interaksi saling pengaruh- mempengaruhi dan saling menunjang satu sama lain (Hamalik, 2014 : 57). Dalam kegiatan mengajar dan belajar terjadi suatu interaksi antara guru sebagai pembelajar dan siswa sebagai subjek dalam belajar. Interaksi yang terjadi tersebut akan mendatangkan hasil belajar. Hasil belajar ini merupakan kemampuan atau perubahan perilaku yang dimiliki siswa setelah ia melakukan interaksi dengan pengajar (guru).

Hasil belajar dapat diartikan sebagai tingkat keberhasilan siswa dalam mempelajari materi pelajaran di sekolah yang dinyatakan dalam skor yang diperoleh dari hasil tes mengenal sejumlah materi pelajaran tertentu. Hasil belajar adalah perwujudan kemampuan akibat perubahan perilaku yang dilakukan oleh usaha pendidikan (Purwanto, 2008: 49). Jadi, hasil belajar adalah perubahan perilaku sebagai perwujudan kemampuan siswa yang diperoleh melalui lingkungan belajarnya dalam kurun waktu tertentu dan dicatat pada sebuah buku rapor sebagai bukti konretnya.

Matematika merupakan salah satu pelajaran dari lima mata pelajaran pokok yang ada di jenjang sekolah dasar. Matematika berasal dari akar kata mathema artinya pengetahuan, mathanein artinya berpikir atau belajar (Hamzah dan Muhlisrarini, 2016: 48). Matematika merupakan salah satu disiplin ilmu yang dapat meningkatkan kemampuan berpikir, memberikan kontribusi dalam penyelesaian masalah sehari-hari dan dalam dunia kerja, serta memberikan dukungan dalam pengembangan ilmu pengetahuan dan teknologi. Oleh karena itu matematika merupakan bidang studi yang menduduki peranan penting dalam bidang pendidikan sehingga mata pelajaran matematika merupakan mata pelajaran yang seharusnya tidak hanya sebatas teori saja, akan lebih baik jika pembelajaran matematika dibuat lebih bermakna dengan mengaplikasikannya dalam kehidupan sehari - hari sehingga pengetahuan yang didapat tidak hanya sebatas teori saja tetapi telah dipraktekkan. Sehingga dengan demikian hasil belajar siswa tampak di masyakarat.

Namun pada kenyataannya masyakarat menganggap bahwa untuk meraih hasil belajar terbaik seseorang haruslah memiliki kecerdasan intelektual (IQ) yang tinggi dan dapat dilihat dengan bukti fisik berupa hasil rapor. Hampir semua orang beranggapan bahwa salah satu ukuran seorang anak bisa dikatakan cerdas apabila ia unggul secara intelektual atau kognitif. Kecerdasan atau intelegensi memang merupakan bekal potensial yang akan memudahkan siswa dalam belajar dan nantinya akan menghasilkan hasil belajar yang optimal. Tetapi kenyataannya yang terjadi di sekolah, ada siswa yang memiliki IQ tinggi tapi hasil belajarnya rendah, dan ada siswa yang memiliki IQ rata - rata atau bahkan IQ-nya rendah tapi hasil belajarnya relatif tinggi. Itulah sebabnya terkadang IQ bukanlah satu - satunya faktor yang menentukan baik atau tidaknya hasil belajar siswa, tapi dikarenakan ada faktor lain yang juga mempengaruhinya.

Daniel Goleman dalam bukunya yang berjudul Emotional Intelligence memperkenalkan sebuah gagasan baru tentang kecerdasan dan juga memberikan bukti bahwa selain IQ, seorang individu juga mempunyai EQ (Emotional Quotient), dimana menurut Goleman bahwa EQ ini lebih penting daripada IQ di dalam kehidupan. "Setinggi-tingginya, IQ menyumbang kira-kira 20 persen bagi faktor-faktor yang menentukan sukses dalam hidup, maka yang 80 persen diisi oleh kekuatan-kekuatan lain" (Goleman: 44). Aunurrahman (2012) menyatakan bahwa telah banyak terbukti bahwa kecerdasan emosi memiliki peran yang jauh lebih signifikan dibanding kecerdasan intelektual (IQ). Yoga (2016: 26) bependapat, orang ber-IQ tinggi juga perlu memiliki EQ yang bagus sehingga memiliki kemampuan hipotesis yang tinggi, mampu mengendalikan dorongan-dorongan hati, dan lebih mampu bertahan. Adanya sinergitas antara IQ dan EQ menjadikan pribadi seseorang menjadi lebih utuh. Tetapi IQ dan EQ saja tidak cukup, karena ada siswa yang memiliki IQ cukup tinggi dan menunjukkan EQ yang baik tetapi hasil belajarnya masih rendah. Agaknya, bukan IQ atau pun EQ yang menentukan suksesnya seseorang, tapi ada faktor lain yang mempengaruhi hasil belajar, terutama hasil belajar matematika siswa. Faktor tersebut adalah Adversity Quotient (AQ) yang dicetuskan oleh Paul G. Stoltz. Kata Adversity bila diartikan dalam bahasa Indonesia bermakna kesulitan atau kemalangan, dan dapat diartikan sebagai suatu kondisi ketidakbahagiaan, kesulitan, atau ketidakberuntungan. Jadi, secara umum dapat dikatakan bahwa AQ merupakan kecerdasan ketahanmalangan, dimana kecerdasan ketahanmalangan dapat diartikan sebagai kemampuan individu dalam menghadapi kesulitan atau kemalangan dan keadaan yang tidak diinginkan. Dalam konsep kependidikan, AQ dapat menjadi faktor yang mempengaruhi hasil belajar siswa, hal itu dikarenakan AQ merupakan sikap pantang menyerah atau sikap ketahanmalangan. AQ dipandang dapat menjadi faktor keberhasilan siswa dalam mencapai hasil belajar yang optimal. Siswa yang memiliki AQ akan berusaha untuk mencari jawaban atas pertanyaan atau permasalahan yang didapat, sehingga secara tidak langsung siswa tersebut akan berfikir kreatif.

Berdasarkan informasi dari hasil wawancara pada tanggal 18 dan 19 Januari 2018 yang diperoleh dari guru kelas V SD Gugus VI Abiansemal, jika diberi tugas untuk mengerjakan soal oleh guru siswa tidak mengerjakannya dengan sungguh-sungguh dan cepat menyerah jika ada soal yang relatif susah. Hal ini juga kadang terjadi pada siswa yang memiliki IQ tinggi, jika mereka dihadapkan dengan soal yang susah, maka tidak sedikit yang cepat menyerah dalam mengerjakan soal tersebut. Jika demikian, maka tentunya keadaan tersebut 
akan berpengaruh pada hasil belajar matematika siswa yang menjadi kurang optimal. Hal ini terlihat pada daftar nilai hasil ulangan akhir matematika semester ganjil yang menunjukkan bahwa dari 165 siswa kelas V SD Gugus VI Abiansemal, 92 siswa masih mendapatkan nilai C, bahkan 2 siswa diantaranya mendapat nilai D.

Dari uraian tersebut maka AQ dipandang dapat menjadi faktor keberhasilan siswa dalam mencapai hasil belajar yang optimal. Siswa yang memiliki AQ akan berusaha untuk mencari jawaban atas pertanyaan atau permasalahan yang didapat, sehingga secara tidak langsung siswa tersebut akan berfikir kreatif. Selain itu, siswa yang memiliki AQ yang cenderung tinggi akan berusaha untuk tidak menyerah dalam menghadapi setiap rintangan dalam menempuh kegiatan pembelajaran. Berdasarkan hal tersebut siswa tidak hanya cukup memiliki IQ tinggi karena IQ bukan satu - satunya yang menjadi tolak ukur keberhasilan siswa dalam mencapai hasil belajar yang optimal, tetapi ada faktor lain yang juga sangat mempengaruhi hasil belajar siswa yaitu Adversity Quotient (AQ).

Stoltz (2007) menggunakan istilah mendaki atau pendakian untuk menganalogikan jenis kepribadian manusia yang bisa menggambarkan kemampuan AQ. Dalam hal ini Stoltz membagi para pendaki gunung menjadi tiga bagian, yaitu: (1) Quitters, (orang-orang yang berhenti atau menyerah) Mereka yang disebut quitters adalah orang yang berhenti melakukan pendakian jauh sebelum menuju puncak atau bahkan menolak terhadap pendakian dan memutuskan untuk berdiam diri. Dalam dunia pendidikan yang dapat dikatakan sebagai quitters adalah siswa yang menyerah dan putus asa dalam menghadapi suatu permasalahan yang ditemuinya dalam pembelajaran. Stoltz (2007) mengungkapkan bahwa seseorang atau siswa yang cenderung memiliki sifat quitters mengabaikan, menutupi, atau meninggalkan dorongan inti yang manusiawi untuk mendaki, dan dengan demikian juga meninggalkan banyak hal yang ditawarkan oleh kehidupan. Sadar atau tidak sadar, seseorang atau siswa yang memiliki sifat quitters selalu melarikan diri dari pendakian, yang berarti juga mengabaikan potensi yang mereka miliki dalam kehidupan ini. (2) Campers, (orang yang berkemah) Mereka yang disebut campers adalah orang yang menghentikan perjalanan (pendakian) dengan dalih ketidakmampuan atau sudah merasa cukup. Mereka beranggapan bahwa berhentinya pendakian adalah sebagai tanda telah dilakukannya berbagai upaya dan pengorbanan. Stoltz menyebutkan para campers adalah satis-ficer yang berarti mereka puas dengan mencukupkan diri, dan tidak mau mengembangkan diri. Para campers telah melewati kaki gunung. Dengan berkemah, mereka mengorbankan bagian puncak, akibatnya campers menjadi sangat termotivasi oleh kenyamanan dan rasa takut. Dalam pembelajaran, siswa yang memiliki sifat campers adalah orang yang sudah berusaha, namun karena ada suatu faktor membuat siswa tersebut menyerah dan kalah atas suatu tantangan dan kesulitan, dan pada akhirnya siswa yang memiliki sifat campers memilih berhenti mendaki dan bertahan pada zona aman. (3) Climbers, (pendaki) Mereka yang disebut climbers adalah orang yang terus bertahan melakukan pendakian sampai pendakian tersebut benar-benar menuju puncak. Mereka tidak menghiraukan lelah dan letih. Mereka juga tidak menghiraukan harta dan tenaga yang telah dikorbankan. Bagi mereka, totalitas dan komitmen adalah keniscayaan. Oleh karena itu, segala bentuk rintangan dan hambatan dinikmatinya sebagai tantangan yang akan mendongkrak dirinya untuk menjadi pahlawan yang sebenarnya. Stoltz (2007) mengungkapkan climbers sangat gigih, ulet, dan tabah. Mereka terus bekerja keras pada waktu mendaki. Kata berhenti tidak terdapat dalam kamus para climbers. Dalam pembelajaran, siswa yang tergolong climbers adalah orang yang mampu menghadapi setiap permasalahan dengan semangat pantang menyerah dan daya tahan yang luar biasa. Mereka mampu menikmati proses menuju keberhasilan, walau mereka tahu bahwa akan banyak rintangan dan kesulitan yang menghadang. Oleh karena itu, siswa tidak hanya cukup memiliki IQ yang tinggi karena IQ bukanlah satu-satunya yang menjadi tolak ukur siswa mendapatkan hasil belajar yang optimal melainkan ada faktor lain seperti Adversity Quotient (AQ) yang dapat mempengaruhi hasil belajar siswa menjadi lebih optimal. Oleh sebab itu, penelitian ini dilakukan untuk mengetahui apakah Adversity Quotient (AQ) berhubungan secara signifikan dengan hasil belajar matematika, penelitian tersebut dilakukan dengan judul "Hubungan Antara Adversity Quotient (AQ) Dengan Hasil Belajar Matematika Siswa Kelas V SD Gugus VI Abiansemal Tahun Ajaran 2017/2018".

\section{Metode}

Penelitian ini dilaksanakan pada semester 2 di kelas V SD Gugus VI Abiansemal. Penelitian ini pada dasarnya bertujuan untuk mengetahui hubungan antara Adversity Quotient (AQ) dengan hasil belajar matematika, dengan tidak memanipulasi variabel bebas atau menggali fakta yang sudah terjadi sebelumnya sehingga penelitian ini tergolong penelitian ex post facto. Agung (2014:56) menyatakan bahwa penelitian ex-postfacto adalah penelitian yang menggunakan suatu pendekatan, dimana gejala (objek) yang diteliti telah ada secara wajar tanpa perlu melakukan eksperimen untuk memunculkan variabel (objek) yang ingin diteliti. Penelitian korelasi merupakan salah satu jenis dari penelitian ex post facto. Darmadi (2014:261) menyatakan bahwa penelitian korelasi merupakan salah satu bagian penelitian ex - postfacto karena biasanya peneliti tidak memanipulasi keadaan variabel yang ada dan langsung mencari keberadaan hubungan dan tingkat hubungan variabel yang direfleksikan dalam koefisien korelasi. 
Berdasarkan penjabaran di atas maka penelitian ini tergolong penelitian ex post facto dengan jenis penelitian korelasi, karena dalam penelitian ini tidak melakukan treatment terhadap variabel-variabel penelitian. Penelitian ini hanya mencari data berdasarkan hasil pengukuran yang telah ada pada para responden.

Dalam sebuah penelitian, pemilihan populasi merupakan hal yang sangat diperlukan. Populasi memegang peran yang penting dalam suatu penelitian karena dari populasi, peneliti dapat menentukan subjek atau sampel yang digunakan dalam penelitian. Seluruh individu yang menjadi subyek penyelidikan yang nantinya akan dikenai generalisasi disebut populasi (Netra,1974:10).

Sugiyono (2012:18) menyebutkan populasi adalah wilayah generalisasi yang terdiri atas, objek/subjek yang mempunyai kualitas dan karakteristik tertentu yang telah ditetapkan untuk dipelajari dan kemudian ditarik kesimpulannya.

Populasi dalam penelitian ini adalah seluruh siswa kelas V SD Gugus VI Abiansemal tahun ajaran 2017/2018 yang terdiri dari 8 sekolah yaitu SDN 1 Mambal,SDN 2 Mambal, SDN 3 Mambal, SDN 4 Mambal, SDN 1 Mekar Bhuana, SDN 2 Mekar Bhuana, SDN 3 Mekar Bhuana, dan SDN 4 Mekar Bhuana yang banyaknya 165 siswa.

Dalam melaksanakan penelitian, selain menentukan populasi, penentuan sampel merupakan hal yang sangat penting untuk mewakili populasi sebagai objek penelitian. Sampel ialah sebagian dari populasi yang diambil, yang dianggap mewakili seluruh populasi dan diambil dengan menggunakan teknik tertentu (Agung, 2014:69).

Dalam penelitian ada banyak sekali teknik yang bisa digunakan untuk mengambil sampel, namun pada penelitian ini teknik yang digunakan dalam mengambil sampel adalah teknik proporsional random sampling. Menurut Netra (1974) teknik sampling proporsional digunakan apabila cara pengambilan sampel memperhitungkan adanya proporsi atau besar kecilnya perbandingan antara bagian-bagian yang ada dalam suatu populasi. Prosedur yang ditempuh dilakukan dengan jalan mengambil individu yang terdapat dalam masing- masing kategori populasi, sesuai dengan proporsi atau perimbangan untuk dijadikan sampel penelitian. Sedangkan menurut Agung (2014:76) teknik sampel proporsional merupakan penyempurnaan dari teknik sampel berstrata dan sampel wilayah. Hal ini dilakukan untuk lebih menjamin representatifnya sampel jika ternyata jumlah subjek yang terdapat dalam tiap strata atau tiap wilayah tidak sama.

Random adalah pengambilan anggota sampel dari populasi dilakukan secara acak. Jadi teknik proporsional random sampling adalah teknik pengambilan sampel secara acak dengan memperhatikan jumlah siswa dari masing- masing kelas. Dengan kata lain, teknik sampling proporsional digunakan untuk mengambil atau menentukan sampel berdasarkan banyak populasi dari masing- masing kelas. Sedangkan random sampling digunakan untuk mengambil atau menentukan sampel pada kelas tersebut secara acak.

Dalam penentuan jumlah sampel dapat dilihat pada tabel Issac and Michel. Dalam tabel tersebut dijelaskan tentang besarnya sampel yang diambil dari populasi dengan tingkat kesalahan 1\%, 5\%, dan $10 \%$. Sesuai dengan tabel tersebut, jumlah populasi di Gugus VI Abiansemal sebanyak 165 orang, sedangkan populasi yang ada dalam tabel Issac and Michel yang mendekati jumlah populasi di Gugus VI Abiansemal adalah 170 orang, jadi jumlah sampel yang diambil dengan tingkat kesalahan 5\% adalah 114 orang.

Data yang dikumpulkan dalam penelitian ini adalah data tentang Adversity Quotient (AQ) dan hasil belajar matematika siswa kelas V SD Gugus VI Abiansemal tahun ajaran 2017/2018. Metode pengumpulan data yang di gunakan dalam penenelitian ini adalah dengan metode kuesioner/angket dan pencatatan dokumen. Kegiatan pengumpulan data dilaksanakan pada siswa yang menjadi sampel di kelas V SD Gugus VI Abiansemal tahun ajaran2017/2018. Pada penelitian ini pengumpulan data tentang Adversity Quotient (AQ) di kumpulkan dengan metode nontes yaitu dengan memberikan angket Adversity Quotient (AQ) . Sedangkan data hasil belajar matematika siswa didapat dengan metode pencatatan dokumen hasil belajar matematika siswa pada semester 1 melalui nilai ulangan akhir semester.

Menurut (Sugiyono, 2012:199) angket adalah teknik pengumpulan data yang dilakukan dengan cara memberi seperangkat pertanyaan atau pernyataan tertulis kepada responden untuk dijawabnya. Sedagkan menurut Darmadi (2014:195), angket adalah suatu daftar pertanyaan tertulis yang terinci dan lengkap yang harus dijawab oleh responden tentang pribadinya atau hal-hal yang diketahuinya. Jadi, dapat dirangkum bahwa angket adalah teknik pengumpulan data yang dilakukan dengan cara memberi seperangkat pertanyaan atau pernyataan tertulis yang digunakan untuk memperoleh informasi dari responden dalam arti laporan tentang pribadinya, atau hal-hal yang ia ketahui.

Penggunaan angket untuk pengumpulan data Adversity Quotient (AQ) siswa diharapkan dapat mengumpulkan informasi yang dibutuhkan dengan cara tidak memberikan pertanyaan atau jawaban secara langsung. Bentuk angket yang digunakan adalah angket berstuktur dengan bentuk jawaban tertutup dimana jawabannya telah tersedia dan responden menjawab setiap pertanyaan dengan cara memilih alternatif jawaban yang telah disediakan. Angket dalam penelitian ini menggunakan skala likert yang akan memudahkan responden dalam menjawab pertanyaan atau pernyataan yang telah disediakan dalam angket tersebut. "Skala likert digunakan untuk mengukur sikap, pendapat, persepsi seorang dan kelompok orang 
tentang fenomena sosial" (Sugiyono,2012 : 134). Jawaban setiap item instrument yang menggunakan skala likert mempunyai gradasi dari sangat positif sampai sangat negatif, yang dapat berupa kata-kata sangat setuju, setuju, ragu-ragu, tidak setuju, sangat tidak setuju. Cara pemberian skornya adalah untuk statement yang positif pilihan sangat setuju skornya 5, setuju skornya 4, ragu-ragu skornya 3, tidak setuju skornya 2 , dan sangat tidak setuju skornya 1 . Sedangkan, untuk statement yang negatif pilihan sangat setuju skornya 1 , setuju skornya 2, ragu-ragu skornya 3, tidak setuju skornya 4, dan sangat tidak setuju skornya 5 .

Pencatatan dokumen dilakukan untuk mengumpulkan data hasil belajar matematika siswa. Menurut Sugiyono (2012:329) dokumen merupakan catatan peristiwa yang sudah berlalu. Sedangkan menurut Darmadi (2014) teknik dokumen adalah cara mengumpulkan data melalui peninggalan tertulis, seperti arsiparsip dan lain-lain yang berhubungan dengan masalah penelitian. Melalui teknik dokumentasi ini akan didapatkan data yang lengkap dan bukan berdasarkan perkiraan.

Untuk menentukan layak tidaknya suatu instrumen maka perlu dites dengan uji validitas. Soalsoal/pernyataan angket Adversity Quotient (AQ) dibuat sendiri dengan mengembangkan soal angket dari ahli masing-masing dan telah diuji validitasnya oleh expert judges. Setelah pengujian validitas dari ahli maka dilanjutkan dengan uji coba instrumen, baru setelah itu akan dilanjutkan dengan pengujian validitas instrumen (angket) dengan menggunakan teknik korelasi product moment.

Dari hasil uji instrumen yang meliputi uji validitas dan uji reliabilitas diperoleh 25 butir soal dari 30 butir soal yang dinyatakan valid dan layak digunakan untuk mengukur Adversity Quotient (AQ) siswa. 1

Setelah mendapatkan data tentang Adversity Quotient (AQ) dan hasil belajar matematika siswa, selanjutnya akan dilakukan uji hipotesis. Sebelum dilakukan uji hipotesis terlebih dahulu dilakukan uji prasyarat analisis, yaitu uji normalitas sebaran data. Uji normalitas dimaksudkan untuk mengetahui apakah sebaran data Adversity Quotient (AQ) dan hasil belajar matematika berdistribusi normal atau tidak sehingga dapat menentukan teknik analisis datanya. Uji Normalitas sebaran data dalam penelitian ini menggunakan teknik Chi-kuadrat. Kriteria pengujian yang digunakan adalah dengan membandingkan nilai $\chi 2$ hitung dengan $\chi 2$ tabel pada taraf signifikan 5\% dengan ketentuan jika $\chi$ 2hitung $<\chi 2$ tabel, maka data berdistribusi normal.

Pada sebaran data Adversity Quotient (AQ) diperoleh $\chi$ 2hitung $=7,71$ dan $\chi 2$ tabel $=11,07$ yang berarti $\chi 2$ hitung $<\chi 2$ tabel maka data berdistribusi normal. Sedangkan pada sebaran data hasil belajar matematika diperoleh $\chi 2$ hitung $=8,90$ dan $\chi 2$ tabel $=11,07$ yang berarti $\chi 2$ hitung $<\chi 2$ tabel maka data berdistribusi normal. Untuk lebih jelasnya dapat dilihat pada tabel berikut.

Tabel 01

Hasil Uji Normalitas Data Adversity Quotient (AQ) dan Hasil Belajar Matematika

\begin{tabular}{|c|c|c|c|}
\hline Variabel & $\chi^{2}$ hitung & $\chi^{2}$ tabel & Ket. \\
\hline $\begin{array}{c}\text { Hasil } \\
\text { Belajar } \\
\text { Matematika }\end{array}$ & 8,90 & 11,07 & $\begin{array}{c}\text { Berdistri } \\
\text { busi } \\
\text { Normal }\end{array}$ \\
\hline $\begin{array}{c}\text { Adversity } \\
\text { Quotient } \\
(\mathrm{AQ})\end{array}$ & 7,71 & 11,07 & $\begin{array}{c}\text { Berdistri } \\
\text { busi } \\
\text { Normal }\end{array}$ \\
\hline
\end{tabular}

Dalam uji hipotesis penelitian ini menggunakan teknik analisis korelasi product moment.. Analisis yang digunakan untuk mengetahui hubungan yang signifikan antara Adversity Quotient (AQ) dengan hasil belajar matematika siswa kelas V SD Gugus VI Abiansemal Tahun Ajaran 2017/2018, yaitu dengan langkahlangkah sebagai berikut: (1) Uji korelasi, dilakukan untuk mengetahui hubungan antara Adversity Quotient (AQ) dengan hasil belajar matematika. Kemudian nilai $r$ yang diperoleh dibandingkan dengan nilai $r$ tabel pada taraf signifikansi 5\% dengan kriteria jika rhitung > rtabel maka H0 ditolak dan Ha diterima. Sebaliknya jika rhitung $\leq$ rtabel maka H0 diterima dan Ha ditolak. (2) Menghitung koefisien determinan, dilakukan untuk menyatakan besar kecilnya sumbangan yang diberikan variabel X (Adversity Quotient) terhadap variabel Y (hasil belajar matematika). (3) Menguji Signifikansi, untuk mengetahui makna hubungan variabel X (Adversity Quotient) dengan variabel Y (hasil belajar matematika). Dengan menggunakan taraf signifikansi 5\%, kritera yang digunakan yaitu, jika thitung $>$ ttabel maka koefisien korelasi tergolong signifikan, sebaliknya jika thitung $\leq$ ttabel maka koefisien korelasi tergolong tidak signifikan. 


\section{Hasil dan Pembahasan}

Berdasarkan hasil analisis data, dapat dideskripsikan bahwa rerata hasil belajar matematika $X=78,20$, $\mathrm{Mo}=79,95, \mathrm{Me}=78,6$, Standar Deviasi $=6,99, \mathrm{Xt}=100, \mathrm{Xr}=60$ sedangkan rerata skor Adversity Quotient (AQ) $\mathrm{X}=104,64, \mathrm{Mo}=105, \mathrm{Me}=104,92, \mathrm{Xt}=121, \mathrm{Xr}=84$ Setelah mendapatkan deskripsi variabel $\mathrm{X}$ (Adversity Quotient) dan variabel Y (hasil belajar matematika), selanjutnya adalah uji hipotesis. Pengujian hipotesis dilakukan dengan $\mathrm{df}=\mathrm{n}-2(114-2)=112$ dan pada taraf signifikansi 5\% diperoleh nilai koefisien korelasi antara Adversity Quotient $(\mathrm{AQ})$ dengan hasil belajar matematika sebesar rxy $=0,537$. Pada taraf signifikansi $5 \%$ dan $\mathrm{df}=112$ diperoleh harga rtabel $=0,184$. Dengan demikian rhitung > rtabel atau 0,537 > 0,184 . Dengan koefisien determinasi sebesar $28,84 \%$ yang berarti Adversity Quotient (AQ) memberikan sumbangan sebesar $28,84 \%$ terhadap hasil belajar matematika. Dan dari hasil analisis diperoleh thitung $=$ 6,738. Pada taraf signifikansi $5 \%$ dan $\mathrm{df}=112$ diperoleh harga ttabel $=1,981$. Dengan demikian thitung > ttabel atau 6,738 >1,981, sehingga $\mathrm{H} 0$ ditolak dan Ha yang berbunyi terdapat hubungan yang signifikan antara Adversity Quotient (AQ) dengan hasil belajar matematika siswa kelas V SD Gugus VI Abiansemal tahun ajaran 2017/2018 diterima. Berikut adalah tabel ringkasan uji hipotesis.

Tabel 02

Ringkasan Uji Hipotesis

\begin{tabular}{|r|r|r|r|r|}
\hline Variabel & rhitung & thitung $_{\text {heterangan }}$ & KP & Ket \\
\hline X dengan $\mathrm{Y}$ & 0,537 & 6,738 & $28,84 \%$ & Signifikan \\
\hline
\end{tabular}

Berdasarkan analisis dari hasil penelitian maka dapat disimpulkan bahwa Adversity Quotient (AQ) memberikan kontribusi sebesar $28,84 \%$ untuk hasil belajar matematika, sedangkan residunya sebesar $71,16 \%$ dipengaruhi oleh faktor lain yang tidak diteliti. Serta berdasarkan analisis dari hasil penelitian diperoleh rhitung $=0,537$ dengan rtabel $=0,184$ yang berarti rhitung $>$ rtabel dan thitung $=6,738$ dengan ttabel $=1,981$ yang berarti thitung > ttabel, sehingga Ha yang berbunyi terdapat hubungan yang signifikan antara Adversity Quotient (AQ) dengan Hasil Belajar Matematika Siswa Kelas V SD Gugus VI Abiansemal Tahun Ajaran 2017/2018, diterima. Hal ini menunjukkan bahwa untuk menentukan keberhasilan siswa dalam belajar tidak hanya berpatok pada kecerdasan intelektual (IQ) saja, melainkan ada faktor lain seperti Adversity Quotient (AQ) yang dapat mempengaruhi keberhasilan siswa dalam belajar. Adversity Quotient (AQ) merupakan salah satu kecerdasan yang dimiliki seseorang dalam mengatasi kesulitan atau kemalangan. Adversity Quotient (AQ) merupakan sikap yang menunjukkan kemampuan seseorang untuk bisa mengatasi segala kesulitan, hambatan, dan kemalangan yang dialaminya. Dalam hal ini, siswa diharapkan mampu untuk megembangkan Adversity Quotient (AQ) yang dimilikinya, sehingga semakin tinggi Adversity Quotient (AQ) yang dimiliki siswa, maka siswa tersebut tidak akan menyerah dalam menghadapi kesulitan dalam belajar, terutama dalam belajar matematika, serta siswa akan selalu berusaha untuk mencari dan menemukan

jawaban dari permasalahan dalam pembelajaran hingga berhasil. Hal ini sesuai dengan teori Stoltz (2007) tentang climbers, yang mengungkapkan bahwa untuk mencapai puncak (keberhasilan) mereka harus berusaha menembus segala rintangan yang menghadang, untuk menghadapi rintangan diperlukan fisik dan pikiran yang sehat serta tekad yang kuat dan tidak pantang menyerah. Hal ini sejalan dengan penelitian Rukmana (2016) yang menyatakan bahwa terdapat hubungan positif yang signifikan antara Adversity Quotient (AQ) dengan hasil belajar matematikasiswa kelas XI SMAN Model Terpadu Madani Palu dengan rhitung = $(0,657)>$ rtabel $=(0,297)$ serta koefisien determinasinya yaitu $\mathrm{r} 2=0,431$ yang menunjukkan bahwa Adversity Quotient (AQ) memberikan pengaruh sebesar $43.1 \%$ terhadap hasil belajar matematika. Dan penelitian ini juga sejalan dengan penelitian yang dilakukan oleh Wardiana (2014) yang menyatakan bahwa terdapat hubungan yang signifikan secara bersama-sama antara Adversity Quotient (AQ) Dan Minat Belajar Dengan Prestasi Belajar Matematika Pada Siswa Kelas V SD Di Kelurahan Pedungan. Hal ini terlihat dari hasil analisis data yang menunjukkan (1) terdapat hubungan yang positif signifikan antara AQ dan prestasi belajar matematika dengan $\mathrm{rx} 1=0,525$ dan koefisien determinasi sebesar $27,56 \%$, (2) terdapat hubungan yang positif signifikan antara minat belajar dan prestasi belajar matematika dengan $\mathrm{rx} 2=0,575$ dan koefisien determinasi sebesar $33,06 \%$, (3) terdapat hubungan yang positif signifikan secara bersama-sama antara AQ dan minat belajar dengan prestasi belajar matematika dengan rx1x2y $=0,639$ dan koefisien determinasinya sebesar $40,83 \%$. Sebagai implikasi dari hasil penelitian ini adalah bahwa guru sebisa mungkin membantu untuk mengembangkan Adversity Quotient (AQ) siswa agar lebih meningkat dimana nantinya Adversity Quotient (AQ) ini bisa meningkatkan hasil belajar matematika siswa. Cara guru mengembangkan Adversity Quotient 
(AQ) siswa adalah dengan menjadi seorang pendengar (listening), yang mendengarkan setiap keluhan dan kesulitan siswa. Kemudian mengamati dan menganalisis (explore and analyze) setiap permasalahan tersebut sehingga guru mampu menyarankan dan melakukan sesuatu (do) (Stoltz, 2007). Guru dapat memberikan saran berupa alternatif jawaban dan siswa dapat mengikuti apa yang menjadi pilihannya berdasarkan saran dan jalan keluar dari guru. Dengan demikian, siswa akan menjadi lebih tahan dalam menghadapi kesulitan dalam belajar, terutama dalam belajar matematika, serta siswa akan selalu berusaha untuk mencari dan menemukan jawaban dari permasalahan dalam pembelajaran hingga berhasil dan Adversity Quotient (AQ) siswa dapat berkembang dengan baik sehingga nantinya siswa mendapatkan hasil belajar yang baik pula.

\section{Simpulan}

Berdasarkan hasil analisis diperoleh rhitung $=0,537$ dengan rtabel $=0,184$ yang berarti rhitung > rtabel, dan koefisien determinannya sebesar 28,84 yang berarti Adversity Quotient (AQ) memberikan kontribusi sebesar 28,84\% untuk hasil belajar matematika, sedangkan residunya sebesar 71,16\% dipengaruhi oleh faktor lain yang tidak diteliti. Serta diperoleh thitung $=6,738$ dan tabel $=1,981$ yang berarti thitung > ttabel, sehingga dapat disimpulkan terdapat hubungan yang signifikan antara Adversity Quotient (AQ) dengan Hasil Belajar Matematika Siswa Kelas V SD Gugus VI Abiansemal Tahun Ajaran 2017/2018.

Apabila berdasarkan uraian tersebut kita mengemukakan interpretasi, maka ini berarti bahwa rata-rata siswa yang tergolong memiliki Adversity Quotient (AQ) tinggi dapat memperoleh hasil belajar matematika yang lebih tinggi daripada siswa yang memiliki Adversity Quotient (AQ) rendah. Berdasarkan hasil penelitian ini, maka dapat diajukan beberapa saran guna peningkatan kualitas pembelajaran yaitu kepada siswa agar lebih mengembangkan Adversity Quotient (AQ) sehingga lebih tahan dan pantang menyerah dalam menghadapi setiap permasalahan yang dihadapi dalam pembelajaran sehingga dapat meningkatkan hasil belajarnya di sekolah terutama hasil belajar matematika.

Berdasarkan temuan penelitian yang diperoleh, disarankan kepada guru lebih mengembangkan Adversity Quotient (AQ) siswa sehingga tujuan pembelajaran tercapai secara optimal.

Kepada kepala sekolah agar dapat menggunakan hasil penelitian ini sebagai pendukung sumber belajar guru dalam meningkatkan kualitas pembelajaran dengan mengembangkan Adversity Quotient (AQ) siswa dalam pembelajaran di sekolah sehingga sekolah mampu menghasilkan siswa yang berkualitas. Serta kepada peneliti lain agar hasil penelitian ini digunakan sebagai referensi untuk melaksanakan penelitian selanjutnya dan semoga penelitian ini bermanfaat bagi seluruh elemen masyarakat yang menggunakan penelitian ini.

\section{Daftar Rujukan}

Agung, A.A Gede. 2013. Buku Ajar Evaluasi Pendidikan. Singaraja: Jurusan Teknologi Pendidikan Fakultas Ilmu Pendidikan Universitas Pendidikan Ganesha

Agung, A.A Gede. 2014. Buku Ajar Metodologi Penelitian Pendidikan. Malang: Aditya Media Publishing

Arikunto, Suharsimi. 2014. Prosedur Penelitian Suatu Pendekatan Praktik. Jakarta: Rineka Cipta

Aunurrahman. 2012. Belajar dan Pembelajaran. Bandung: Alfabeta

Dahar, Ratna Wilis. 2011. Teori-Teori Belajar \& Pembelajaran. Jakarta: Erlangga

Dantes, Nyoman. 2012. Metode Penelitian. Yogyakarta: Andi Offset

Dantes, Nyoman. 2014. Analisis dan Desain Eksperimen Disertai Contoh Penerapan Analisis Data. Singaraja: Program Pascasarjana Undiksha

Darmadi, Hamid. 2014. Metode Penelitian Pendidikan dan Sosial.

Goleman, Daniel. -. Emotional Intelligence. Jakarta: Gramedia Pustaka Utama

Hamalik, Oemar. 2014. Kurikulum dan Pembelajaran. Jakarta: Bumi Aksara

Hamzah, Ali dan Muhlisrarini. 2016. Perencanaan dan Strategi Pembelajaran Matematika. Jakarta: Raja Grafindo Persada

Japa, Gusti Ngurah dan Made Suarjana. 2015. Buku Ajar Pendidikan Matematika I. Singaraja: Universitas Pendidikan Ganesha

Koyan, I Wayan. 2011. Asesmen Dalam Pendidikan. Singaraja: Universitas Pendidikan Ganesha Press

Netra. 1974. Statistik Inferensial. Surabaya: Usaha Nasional

Purwanto. 2008. Evaluasi Hasil Belajar. Daerah Istimewa Yogyakarta: Pustaka Pelajar

Riduwan dan Akdon. 2013. Rumus dan Data dalam Aplikasi Statistika. Bandung: Alfabeta

Rukmana, dkk. 2016. "Hubungan Adversity Quotient Dengan Hasil Belajar Matematika Siswa Kelas XI SMA Negeri Model Terpadu Madani Palu”. Tersedia pada http://jurnal.untad.ac.id/jurnal/index. php/JEPMT/article/view/7220/5809 (diakses tanggal 2 Januari 2018)

Sagala, Syaiful. 2012. Konsep dan Makna Pembelajaran. Bandung: Alfabeta

Setyosari, Punaji. 2015. Metode Penelitian Pendidikan \& Pengembangan. Jakarta: Prenadamedia Group

Slameto. 2010. Belajar dan Faktor-faktor Yang Mempengaruhinya. Jakarta: Rineka Cipta 
Stoltz, Paul G. 2004. Adversity Quotient: Mengubah Hambatan Menjadi Peluang. Jakarta: Grasindo Stoltz, Paul G. 2007. Adversity Quotient: Mengubah Hambatan Menjadi Peluang. Jakarta: Grasindo

Suandi, I Nengah dkk. 2016. Pedoman Penulisan Karya Ilmiah Tugas Akhir, Skripsi, Tesis, dan Disertasi. Singaraja:Universitas Pendidikan Ganesha

Sugiyono. 2012. Metode Penelitian Pendidikan. Bandung: Alfabeta

Sugiyono. 2017. Statistika Untuk Penelitian. Bandung: Alfabeta

Supardi. 2013. Aplikasi Statistika dalam Penelitian Konsep Statistika yang lebih Komprehesif. Jakarta Selatan: PT. Prima Ufuk Semesta

Susanto, Ahmad. 2013. Teori Belajar dan Pembelajaran di Sekolah Dasar. Jakarta: Kencana Prenadamedia Group

Wardiana, dkk. 2014. "Hubungan Antara Adversity Quotient (AQ) Dan Minat Belajar Dengan Prestasi Belajar Matematika Pada Siswa Kelas V SD Di Kelurahan Pedungan”. Tersedia pada https://ejournal.undiksha.ac.id/index. php/JJPGSD/article/viewFile/3026/2 510 (diakses tanggal 2 Januari 2018)

Yoga, Miarti. 2016. Adversity Quotient: Agar Anak Tak Gampang Menyerah. Solo: Tiga Serangkai Pustaka Mandiri 